\title{
Extraction and Utilization of Manihot esculenta crantz and Trapa natans Starch as a Stabilizer in Soy Milk Based Ice Cream Preparation
}

\author{
Muhammad Faisal Manzoor* and Nazir Ahmed \\ Institute of Home and Food Sciences, Government College University Faisalabad, Pakistan
}

Submission: June 28, 2017; Published: July 17, 2017

"Corresponding author: Muhammad Faisal Manzoor, Institute of Home and Food Sciences, Government College University Faisalabad, Pakistan, Tel: +92-343-7843953; Email: faisaluos26@gmail.com

\begin{abstract}
Stabilizers are important ingredient in ice cream manufacturing. It improves mix viscosity, air incorporation, air cell distribution, texture, melting properties and minimize quality defect. Soy milk used for milk replacer due to its health benefits such as dietary fiber, protein, isoflavones, vitamin C, carotenoids, omega-3-fatty acid and oligosaccharides. Starches were extracted from Trapa natans and manihot esculenta crantz analyzed for different quality parameters for $\mathrm{pH}$, water binding capacity, swelling power and solubility, moisture, protein and viscosity. The starch extracted from Trapa natans showed better results against all the quality parameters as compare to manihot esculenta crantz starch. Soy milk based ice cream was prepared using different percentages of $(0.25,0.5$ and $0.75 \%)$ Trapa natans and manihot esculenta crantz starches as stabilizer. Cremodan stabilizer was used as reference standard. Ice cream was characterized for physicochemical and sensory attributes. Ice cream sample prepared with $0.75 \%$ of Trapa natans starch showed significant $(\mathrm{P}<0.05)$ results in term of high overrun, meltdown, standup time and viscosity. The development of soy milk based ice cream with novel starches from natural sources provides extra health benefits and reduce the cost of production.
\end{abstract}

Keywords: Manihot esculenta crantz; Trapa natans; Starch; Stabilizer; Soy milk, Ice cream preparation

Abbreviations: SNF: Solid Not Fat; cP: Centipoise; CRD: Completely Randomized Design; SPSS: Statistical Package for the Social Sciences

\section{Introduction}

A novel trend in functional foods has been pointed out as the production of non-dairy food products [1]. Functional ingredients such as, prebiotic, probiotic, soy and their derivatives grow $5 \%$ per year in the market of food products worldwide [2]. Soy based products have potential for alternative of cow milk. Soybeans are good source of carbohydrates and proteins (high quality) but free from cholesterol and lactose. It is a potential milk substitute source for milk allergy patients (lactose intolerance) and vegetarians [3]. Soybean proteins affect the cholesterol metabolism and fecal excretion of bile acids [4]. Soy milk have different health benefits such as dietary fiber, protein, isoflavones, vitamin C, carotenoids, omega-3-fatty acid and oligosaccharides. Soybean composes of $15-16 \%$ dietary fiber, $39-40 \%$ protein, $14-15 \%$ saccharides, $19-20 \%$ oil contents, and $10-11 \%$ others miscellaneous nutrients [5].
Stabilizers are important ingredients of ice cream manufacturing. The amount of stabilizer used depends upon desired quality of the end product. The stabilizers during dispersion hold the flavoring compound provide good aroma and help to hinder air bubbles from collapsing [6]. The main functions of stabilizer are to increase the mix viscosity, prevented separation of proteins, whipping properties improvement, texture development, retarded ice crystal growth, increase the melting resistance and regulate the sensory properties [7].

Trapa natans is an important native crop in Asia and many other parts of world. Due to its unique taste, it is a significant product in food industry [8]. Trapa natans is a good source of starch present large prospective for commercial use. Trapa natans for domestic and industrial use, is great source of starch due to its more carbohydrate contents. Because of their characteristics 
like: solubility, gelatinization, freeze thaw stability, swelling properties starches are famous to impart functionality in range of dairy products [9]. Starches are used as coagulating agents (pie fillings, cream soups and sauces), gel-forming agents (gum confections), moisture retainers (cake toppings), colloidal stabilizers (salad-dressings), binders (cones, wafers), coating agents (candies, nutmeats) and varnishing. Functions of starch depend upon its physicochemical properties in various foods [10]. Uses of starches in products are mainly directed due its pasting, solubility, gelatinization, swelling, digestibility and color [11].

Manihot esculenta crantz with tuberous roots is a perennial woody shrub [12]. In Asia, America (Latin) and Africa Manihot esculenta crantz after maize and rice cultivated as the third most important source of calories. In 2012, its production in all over the world was evaluated as $262,585,741$ tons [13]. Availability of Manihot esculenta crantz is around the year due the planting and harvesting flexibility of crop. Nutritionally, its roots assumed a better source of dietary fiber, riboflavin, magnesium, nicotinic acid, citrate and thiamin, but not good source of protein [14]. Excluding consumption, its roots is mostly used for different industrial purpose such as ethanol and biofuel production [15]. Starch form Manihot esculenta crantz roots are the vital component and obtained up to $80 \%$ of dried weight [16]. Application in food industries as thickeners (soups, baby foods, sauces, and gravies), fillers, binders (sausages and processed meats) and as a stabilizers (ice cream) [17].

Worldwide population is regularly increase and malnutrition in developing countries is occurred due to insufficient supply of protein. Protein from animal source is expensive in developing countries, fulfil the demands of protein, research effort to finding alternative sources of protein from legume seeds [18]. Due to significance of soy milk and carbohydrate the present study was planned to add the manihot esculenta crantzand Trapa natans starches in different concentrations in the locally prepared soy milk for the preparation of ice cream.

\section{Material and Methods}

\section{Procurement of raw material}

Soya beans and Trapa natans was purchased from the local market for soy milk preparation and starch extraction respectively. Manihot esculenta crantz roots was purchased from Zamzam Enterprises, Global Exporters of fresh products are based in Karachi, Pakistan. Other ingredients such as sugar, egg yolk, stabilizer (Trapa natans and Manihot esculenta crantz starch) artificial flavor and food grade color (FD\&C yellow, 5) were purchased from the local market. For physicochemical analysis of soy milk, ice cream and starches all chemical and reagents were acquired from Sigma Aldrich (USA), Merck (Germany) and Oxoid (UK).

\section{Preparation of soy milk}

Soybeans $(200 \mathrm{~g})$ were washed in de-ionized water. The cleaned beans were soaked in $1 \mathrm{~L}$ of water for $13-14 \mathrm{~h}$ at $4-5{ }^{\circ} \mathrm{C}$.
Then swollen soybeans after separation were blend at low speed in 1 liter of boiling water for 5-6min. The obtained slurry was heated for $10 \mathrm{~min}$ at $80{ }^{\circ} \mathrm{C}$ and then filtration was done through four layers of cheese cloth. The soy milk filtrate (1650g) was collected and cooled at room temperature and then kept at $4{ }^{\circ} \mathrm{C}$ [19] (Figure 1).

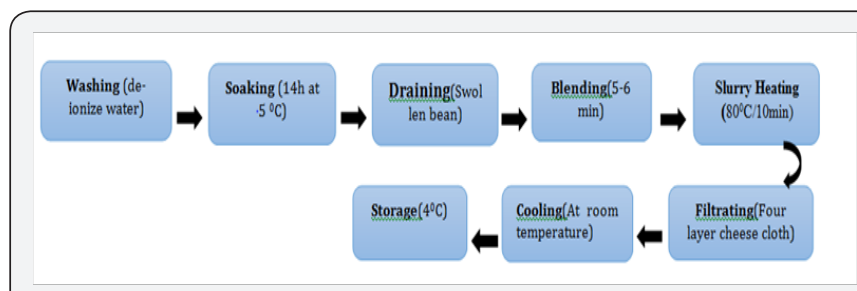

Figure 1: Flow diagram of the preparation of soy milk.

\section{Analysis of soy milk}

The $\mathrm{pH}$ of soy milk was measured by using the electronic digital pH meter (Inolab WTW Series 720) [20]. Fat, total nitrogen, ash, acidity and total solid contents were estimated by the method described by AOAC [20]. The solid not fat was calculated according to the method described Kirk \& Sawyer [21].

\section{Starch extraction}

Starch from Trapa natans and Manihot esculenta crantz were extracted by using the method described by Tulyathan et al. [22] and Benesi et al. [23] respectively.

\section{Analysis of starches}

The $\mathrm{pH}$ of both starches was measured by using the electronic digital $\mathrm{pH}$ meter. Buffer solution of $\mathrm{pH} 4$ and 7 were used for calibration of pH meter [24]. Fat, moisture, ash and total nitrogen content were evaluated according to method AOAC [20]. Water binding capacities of dried starches were estimated by the method described by Garg \& Jana [25]. The viscosity was measured by using Viscometer by the method of Mweta [26]. Swelling power and solubility were calculated according to the method of Garg \& Jana [25].

\section{Preparation of ice cream}

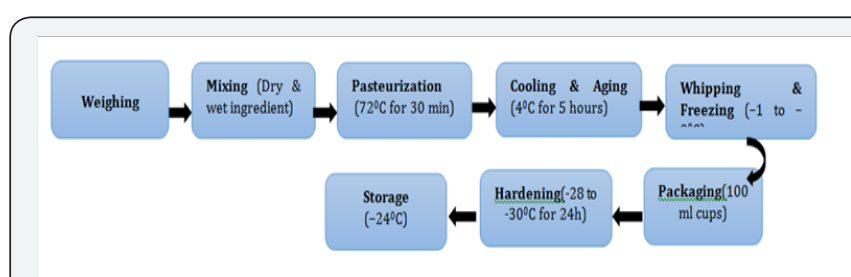

Figure 2: Flow diagram of the preparation of ice cream.

The dry ingredients sugar and stabilizers were weighed and mixed with liquid ingredients by constant stirring. Starches were used in different concentrations $(0.25,0.5$ and $0.75 \%)$ for ice cream preparation as shown in Table 1 . The obtained mixture was pasteurized at $72{ }^{\circ} \mathrm{C}(30 \mathrm{~min})$ and then by using electric homogenizer homogenization was done. After that, ageing was done at $4{ }^{\circ} \mathrm{C}(5 \mathrm{~h})$. The mixture was further subjected -1 to 
$-9{ }^{\circ} \mathrm{C}$ along with whipping. For physicochemical and sensory evaluation ice cream was filled in $100 \mathrm{ml}$ disposable cup [27] (Figure 2 \& Table 1).

Table 1: Different concentrations of Trapa natans and Manihot esculenta crantz for the preparation of soy milk based ice cream.

\begin{tabular}{|c|c|c|c|c|}
\hline Treatments & $\begin{array}{c}\text { Trapa } \\
\text { natans } \\
\text { Starch }\end{array}$ & $\begin{array}{c}\text { Manihot } \\
\text { Esculenta } \\
\text { Crantz } \\
\text { Starch }\end{array}$ & $\begin{array}{c}\text { Cremodon } \\
\text { (\%) }\end{array}$ & Total (\%) \\
\hline T0 & 0 & 0 & 0.5 & $0.50 \%$ \\
\hline T1 & 0.25 & 0 & 0 & $0.25 \%$ \\
\hline T2 & 0 & 0.25 & 0 & $0.25 \%$ \\
\hline T3 & 0.5 & 0 & 0 & $0.50 \%$ \\
\hline T4 & 0 & 0.5 & 0 & $0.50 \%$ \\
\hline T5 & 0.75 & 0 & 0 & $0.75 \%$ \\
\hline T6 & 0 & 0.75 & 0 & $0.75 \%$ \\
\hline
\end{tabular}

\section{Physicochemical analysis ice cream}

Ice cream $\mathrm{pH}$ was measured with the help of $\mathrm{pH}$ meter according to the method of AOAC [24]. Overrun of prepared samples were estimated according to the Varnam \& Sutherland [28]. Melt-ability of all prepared ice cream samples were estimated by the method described by Olsonet al. [29]. 100gm of ice cream was placed on mesh which fitted on a beaker. The melted ice cream weight after every $15 \mathrm{~min}$ interval up to $75 \mathrm{~min}$ was recorded at $26 \pm 3{ }^{\circ} \mathrm{C}$. Mix viscosity (cP) was calculated by using Brookfield viscometer spindle No. 4 at $100 \mathrm{rpm}$ just before and after aging at $25^{\circ} \mathrm{C}$ and $5{ }^{\circ} \mathrm{C}[30]$. Standup time of ice cream mix was measured by method of Bhandari [31].

\section{Sensory evaluation}

After storage at $-22{ }^{\circ} \mathrm{C}$ for 24 hours, all samples were judge by 5 staff members of Institute of Home and Food Sciences, Government College University Faisalabad according to the method described by Larmond [32]. Expert panel evaluates the impact of Trapa natans and Manihot esculenta crantz as stabilizers on taste, flavor, texture and overall acceptability of ice cream.

\section{Statistical analysis}

Data statistically analyzed for the effects of the factors on $\mathrm{pH}$, viscosity, standup time, over-run, melt-ability and sensory evaluation was done by CRD using SPSS software to estimate the significance level [33]. The factors were: type of stabilizers (Trapa

natans and Manihot esculenta crantz starch) and concentration $(0.25,0.5$ and $0.75 \%)$.

\section{Results and Discussion}

\section{Analysis of soy milk}

Soy milk was analyzed for different physicochemical parameters. Mean value of these perimeters are following, such as $\mathrm{pH}(6.72-6.75)$, acidity $(0.28 .0 .30 \%)$, ash (0.7-0.73\%), protein (3.3-3.32\%), SNF (10-10.2\%) and total Solids (12.7-12.74\%). Obtained results from present study are in line with the findings of Jooyandeh [34].

\section{Analysis of starches}

Trapa natans and Manihot esculenta crantz were subjected for different physicochemical analysis and all were performed in triplicate. Mean values for Trapa natans starch of all performed physicochemical parameters are following; pH (5.58 \pm 0.35$)$, fat $(0.25 \pm 0.01)$, water holding capacity $(81.73 \pm 1.50)$, swelling power $(3.0 \pm 0.2)$, solubility $(2.3 \pm 0.7)$, moisture $(9.5 \pm 0.5)$, protein $(0.5 \pm 0.03)$ and viscosity $(3394 \pm 55 \mathrm{cP})$. Mean values of physicochemical analysis for Manihot esculenta crantz starch are following; $\mathrm{pH}(5.36 \pm 0.25)$, fat $(0.25 \pm 0.01)$, water holding capacity (78 \pm 1.05$)$, swelling power $(2.5 \pm 0.3)$, solubility $(1.8 \pm 0.2)$, moisture $(8.3 \pm 0.5)$, protein $(0.1 \pm 0.02)$ and viscosity $(2870 \pm 35 \mathrm{cP})$. The $\mathrm{pH}$, water holding capacity, swelling power, solubility, moisture, crude protein and viscosity of Trapa natans starch were better than Manihot esculenta crantz except fat content (Table 2). The results regarding to physicochemical characteristics of starches are in line with the finding of Oladebeye et al. [35] and Gomand et al. [36] (Table 2).

Table 2: Physicochemical analysis of Trapa natans and Manihot esculenta crantz starches.

\begin{tabular}{|c|c|c|}
\hline Parameter & $\begin{array}{c}\text { Trapa natans } \\
\text { starch }\end{array}$ & $\begin{array}{c}\text { Manihot esculenta } \\
\text { crantz starch }\end{array}$ \\
\hline $\mathrm{pH}$ & $5.58 \pm 0.35$ & $5.36 \pm 0.25$ \\
\hline Fat (\%) & $0.25 \pm 0.01$ & $0.30 \pm 0.02$ \\
\hline $\begin{array}{c}\text { Water binding } \\
\text { capacity (\%) }\end{array}$ & $81.73 \pm 1.50$ & $78 \pm 1.05$ \\
\hline Swelling power (\%) & $3.0 \pm 0.2$ & $2.5 \pm 0.3$ \\
\hline Solubility (\%) & $2.3 \pm 0.7$ & $1.8 \pm 0.2$ \\
\hline Moisture (\%) & $9.5 \pm 0.5$ & $8.3 \pm 0.5$ \\
\hline Crude protein (\%) & $0.5 \pm 0.03$ & $0.1 \pm 0.02$ \\
\hline Viscosity (cp) & $3394 \pm 55$ & $2870 \pm 35$ \\
\hline
\end{tabular}

Table 3: Comparison of mean values for physicochemical characteristics influenced by treatments.

\begin{tabular}{|c|c|c|c|c|c|c|}
\hline \multirow{2}{*}{ Treatment* } & \multicolumn{3}{|c|}{ pH } & \multicolumn{3}{c|}{ Viscosity (cP) } \\
\cline { 2 - 7 } & Fat (\%) & Before Aging & After Aging & Before Aging & After Aging & Overrun $\%$ \\
\hline To & $2.51 \pm .02$ & $7.29 \pm 0.05$ & $7.36 \pm 0.10$ & $2950 \pm 20$ & $4250 \pm 18$ & $53.54 \pm 0.26$ \\
\hline T1 & $2.45 \pm .01$ & $7.19 \pm 0.07$ & $7.25 \pm 0.11$ & $2360 \pm 21$ & $3460 \pm 17$ & $44.76 \pm 0.64$ \\
\hline T2 & $2.47 \pm .03$ & $7.15 \pm 0.08$ & $7.22 \pm 0.09$ & $1950 \pm 18$ & $2750 \pm 14$ & $39.48 \pm 0.60$ \\
\hline T3 & $2.48 \pm .03$ & $7.25 \pm 0.04$ & $7.31 \pm 0.07$ & $2646 \pm 16$ & $3846 \pm 20$ & $47.85 \pm 0.58$ \\
\hline T4 & $2.49 \pm .04$ & $7.20 \pm 0.06$ & $7.26 \pm 0.11$ & $2126 \pm 15$ & $3026 \pm 21$ & $41.76 \pm 0.70$ \\
\hline
\end{tabular}




\section{Agricultural Research \& Technology: Open Access Journal}

\begin{tabular}{|l|l|l|l|l|l|l|}
\hline T5 & $2.51 \pm .02$ & $7.30 \pm 0.03$ & $7.37 \pm 0.08$ & $3053 \pm 16$ & $4453 \pm 15$ & $54.68 \pm 0.65$ \\
\hline T6 & $2.52 \pm .05$ & $7.26 \pm 0.09$ & $7.30 \pm 0.06$ & $2443 \pm 15$ & $3543 \pm 22$ & $44.20 \pm 0.52$ \\
\hline
\end{tabular}

\section{Analysis of soy milk base ice cream}

It was clear from all statistical outcomes fat content significantly $(\mathrm{P}<0.05)$ varies among all the treatments. Highest value for fat content $(2.52 \pm .02)$ was obtained for T6 having $0.75 \%$ concentration of Manihot esculenta crantz (Table 3 ). The fat content varies among all the treatment due to the fat content difference present in both starches and among all the treatments concentration of starches were different.

Statistical results indicate that $\mathrm{pH}$ of all ice cream samples significantly $(\mathrm{p}<0.05)$ differ among all treatments. On aging, $\mathrm{pH}$ value of all treatments were increased, this trend is accordance with Akesowan [37]; Rezaei et al. [38]. The highest mean value of $\mathrm{pH}$ before the aging $(7.30 \pm 0.03)$ and $(7.37 \pm 0.08)$ after the aging were recorded in $\mathrm{T} 5$ while other have low $\mathrm{pH}$. In dairy products, due to compositional and biochemical changes, $\mathrm{pH}$ has direct influence on the flavor perception during aging [39]. Results shows that the ice cream containing $0.75 \%$ concentration of Trapa natans starch had the least decreased in $\mathrm{pH}$ and due to less production of acidity.

Statistically, the effect of different concentrations of stabilizers on the viscosity of soy milk ice cream found significant $(\mathrm{P}<0.05)$ among all the treatments. The interaction of stabilizers was found linear, with increasing the concentration of starch viscosity also increase. The highest value of viscosity before aging ( $3053 \pm 16)$ and $(4453 \pm 15)$ after aging was observed for Trapa natans starch at concentration of $0.75 \%$ as compare to the controlled. The factors affecting the viscosity during this study, temperature, fat globule size, protein hydration, type and concentration of stabilizers. Flavor and mouth feel of ice cream mix was provided by viscosity [40]. Viscosity is also increase if fat and protein content increase, but these components in all samples remain same. So, viscosity was increase only due to different type and concentration of stabilizers [41]. Rheological properties of ice cream affected due to high water holding capacity of starches $[42,43]$.

Overrun among all treatments also significantly $(\mathrm{P}<0.05)$ effected, because stabilizer type and concentration had a significant effect. The highest value $(54.68 \pm 0.65)$ was observed for Trapa natans starch at $0.75 \%$ concentration shown in Table 3. Ice crystals and air cells become smaller if overrun decrease [44]. Ice cream volume loss due to collapse of weakened film reported by Potter and Hotchkiss [45]. Air loss from ice cream mix the shrinkage was reported by Rothwell [46]. Air incorporation is important due to overrun property, product quality and profits. The less and more air incorporation produce soggy and fluffy ice cream respectively [47] (Table 3).

After melting first drop of ice cream fell was noted for each sample. Addition of both starches at different concentrations showed significant $(\mathrm{P}<0.05)$ effect on the stand up time of soy milk ice cream (Table 4). At $0.75 \%$ concentration of Trapa natans starch, highest mean value of standup time before and after aging were observed, $12.10 \pm 0.12$ and $18.10 \pm 0.14$ respectively. While the lowest values were observed in ice cream sample T4 before and after aging shown in Table 3. Investigation shows that significant variation in standup time, by increasing the quantity of starches and due to their binding ability. Normal standup time for ice cream is 13 minutes at $20^{\circ} \mathrm{C}$ [48].

Table 4: Comparison of mean values for physicochemical characteristics influenced by treatments.

\begin{tabular}{|c|c|c|c|c|c|c|c|}
\hline \multirow{2}{*}{ Treatments* } & \multicolumn{2}{|c|}{ Standup Time (min.) } & \multicolumn{5}{|c|}{ Melt ability \% Time (min.) } \\
\hline & Before aging & After aging & 15 & 30 & 45 & 60 & 75 \\
\hline To & $11.20 \pm 0.10$ & $17.20 \pm 0.17$ & 1.32 & 5.28 & 19.93 & 40.93 & 62.52 \\
\hline $\mathrm{T} 1$ & $9.45 \pm 0.14$ & $14.35 \pm 0.18$ & 1 & 4 & 24.2 & 45.2 & 66.65 \\
\hline $\mathrm{T} 2$ & $7.21 \pm 0.11$ & $10.21 \pm 0.10$ & 2.02 & 8.06 & 30.2 & 51.2 & 70.34 \\
\hline $\mathrm{T} 3$ & $10.2 \pm 0.15$ & $15.18 \pm 0.11$ & 0.66 & 2.64 & 21.2 & 41.2 & 62.89 \\
\hline $\mathrm{T} 4$ & $8.01 \pm 0.12$ & $12.10 \pm 0.13$ & 1.56 & 6.2 & 27.56 & 47.2 & 67.75 \\
\hline T5 & $12.10 \pm 0.12$ & $18.10 \pm 0.14$ & 0.34 & 1.38 & 18.96 & 39.23 & 60.23 \\
\hline T6 & $9.05 \pm 0.13$ & $13.05 \pm 0.10$ & 1.2 & 4.8 & 26.5 & 45.45 & 65.2 \\
\hline
\end{tabular}

*See Table 1: (LSD at 0.05 value for melting resistance; Treatments=0.556; Time=0.5625; Interactions=1.1797).

Melt-ability shows that the melting resistance of ice cream samples. Melt-ability was decrease, due to the air incorporation and quality of end product increased. Statistically, it was observed that all melt-ability significant $(\mathrm{P}<0.05)$ varies among all treatments according to time $(0,15,30,45,60$ and $75 \mathrm{~min}$.). Overall the highest (70.34) and lowest (60.23) melt-ability after $75 \mathrm{~min}$ were observed for $\mathrm{T} 2$ and $\mathrm{T} 5$ (Table 4). The factors effecting the melt-ability of ice cream, composition, additives and many other, air incorporated, ice crystals, fat globules, type and nature of stabilizers [49]. The ice cream sample having highest overrun began to melt slowly and vice versa due to binding ability of starches. Low freezing point and environmental conditions are primary reason of rapid melting [48]. Melt-ability of the ice cream is reduce, by the controlling heat transfer, outside temperature and homogenization [50](Table 4). 


\section{Agricultural Research \& Technology: Open Access Journal}

\section{Sensory evaluation of soy milk base ice cream}

Table 5: Comparison of mean values for sensory characteristics influenced by treatments.

\begin{tabular}{|c|c|c|c|c|c|c|c|}
\hline Treatment & T0 & T1 & T2 & T3 & T4 & T5 & T6 \\
\hline Flavor & $7.4 \pm 0.54$ & $6 \pm 0.83$ & $5.4 \pm 0.54$ & $6.8 \pm 0.70$ & $5.8 \pm 0.89$ & $7.8 \pm 0.83$ & $6.2 \pm 0.81$ \\
\hline Taste & $7.6 \pm 0.54$ & $6.2 \pm 0.70$ & $5.5 \pm 0.50$ & $6.9 \pm 0.81$ & $5.9 \pm 0.53$ & $7.9 \pm 0.70$ & $6.4 \pm 0.85$ \\
\hline Appearance & $7.7 \pm 0.83$ & $6.2 \pm 0.83$ & $5.6 \pm 0.52$ & $7.2 \pm 0.83$ & $6.4 \pm 0.54$ & $8.0 \pm 0.70$ & $6.8 \pm 0.80$ \\
\hline Body/Texture & $7.6 \pm 0.54$ & $5.8 \pm 0.80$ & $5.4 \pm 0.50$ & $6.7 \pm 0.70$ & $5.8 \pm 0.89$ & $7.8 \pm 0.83$ & $6.4 \pm 0.80$ \\
\hline $\begin{array}{c}\text { Overall } \\
\text { acceptability }\end{array}$ & $7.8 \pm 0.83$ & $6.0 \pm 0.70$ & $5.8 \pm 0.80$ & $7.0 \pm 0.83$ & $6.2 \pm 0.85$ & $8.0 \pm 0.70$ & $6.6 \pm 0.70$ \\
\hline
\end{tabular}

Sensory properties of soy milk ice cream as affected by different type and concentration of stabilizers (Table 5). Samples were evaluated for appearance, taste, flavor, body and overall acceptability, by the panel of 5 judges. All the sensory parameters were significantly affected by the concentration of Trapa natans and Manihot esculenta crantz as compare to control. The ice cream sample get highest awarded by judges panel containing $0.75 \%$ Trapa natans starch followed by the ice cream containing $0.5 \%$ Trapa natans starch. While ice cream containing Manihot esculenta crantz as a stabilizers got the lowest scores. Difference in all sensory parameters was observed due the difference of starch color and taste because the Manihot esculenta crantz is sour or fermented taste and dark in color on drying but Trapa natans is sweet in taste and white in color (Table 5).

\section{Conclusion}

Locally prepared soy milk was used successfully to prepare soy milk based ice cream. Main purpose of this study to prepared soy milk based ice cream for consumers due to their different health benefits anti-allergenic, anti cholesterolemic, anti atherogenic and hypolipidemic properties. Recommended stabilizer for ice cream could be Trapa natans starch at $0.75 \%$ for best viscosity, over-run, meltdown, standup time and sensory parameters. It is concluded that ice cream made with locally available Trapa natans starch as stabilizer showed the comparable results from commercially used imported stabilizer. Therefore, by using locally available stabilizers, the production cost can be minimized and foreign exchange can be saved. The ethical concerns have resulted in a global interest for Halal and natural stabilizer. Moreover, soy milk based ice cream also has potential for commercialization as a frozen dessert.

\section{Acknowledgments}

It certify that the author do not have any affiliation for any financial interest with in any organization.

\section{References}

1. Kano M, Ishikawa F, Matsubara S, Kikuchi-Hayakawa H, Shimakawa Y (2002) Soymilk products affect ethanol absorption and metabolism in rats during acute and chronic ethanol intake. J Nutr 132(2): 238-244.

2. Granato D, Branco GF, Cruz AG, Faria JDAF, Shah NP (2010) Probiotic dairy products as functional foods. Compr Rev Food Sci Food Saf 9(5): 455-470.
3. Liu JR, Lin CW (2000) Production of kefir from soymilk with or without added glucose, lactose, or sucrose. J Food Sci 65(4): 716-719.

4. Tomat AL, Costa MADIA, Arranz CT (2011) Zinc restriction during different periods of life: Influence in renal and cardiovascular diseases. Nutr 27(4): 392-398.

5. Kim JJ, Kim SH, Hahn SJ, Chung MI (2005) Changing soybean isoflavone composition and concentrations under two different storage conditions over three years. Food Res Inter 38(4): 435-444.

6. Ardabili G, Ashraf (2005) Effect of data syrup as a substitute for sugar on the physicochemical and sensory properties of soft ice cream. Iranian Food Sci Technol Res J 1(2): 23-31.

7. Hanne K (2011) Manufacturing high quality ice cream with high overrun. Palsguard Technology Paper 1-4.

8. Parker CC, Parker ML, Smith CA, Waldron KW (2003) Thermal stability of texture in Chinese Trapa natans may be dependent on 8-diferulic acid (aryltetrlyn form). J Agri Food Chem 51(7): 2034-2039.

9. Demiate MI, Oetterer M, Wosiacki G (2001) Characterization of chestnut (castanea sativa, mill) starch for industrial utilization. Braz Arch Biol Technol 44(1): 69-78.

10. Kaletunc G, Breslauer JK (2003) Starch Properties and Functionalities, Characterization of cereals and flours. Library of Congress Cataloging in Publication Data Marcel Dekker, New York, pp. 492-493.

11. Adebowale KO, Lawal OS (2003) Functional properties and retro gradation behavior of native and chemically modified starch of mucuna bean (Mucunapruriens). J Sci Food Agri 83(15): 154-156.

12. Alves AAC (2002) Cassava botany and physiology. In: Hillocks RJ, Thresh JM (Eds.), Cassava: Biology, Production and Utilization, Brazil, pp. 67-89.

13. Food and Agricultural Organization (2014) The Statistical Division. FAO, Rome, Italy.

14. Westby A (2002) Cassava utilization, storage and small-scale processing. In: Hillocks RJ, Thresh JM, Belloti AC (Eds.), Cassava: Biology, Production and Utilization, CAB International Publishing, Wallingford, UK, pp. 281-300

15. Lu Y, Ding Y, Wu Q (2011) Simultaneous saccharification of Manihot esculenta crantz and fermentation of algae for biodiesel production. J Appl Phycol 23(1): 115-121.

16. Olomo V, Ajibola O (2003) Processing factors affecting the yield and physicochemical properties of starch from cassava chips and flour. Starch-Stärke 55(10): 476-481.

17. Perez JC, Lenis JI, Calle F, Morante N, Sanchez T, et al. (2011) Genetic variability of root peel thickness and its influence in extractable starch from cassava (Manihot esculenta Crantz) roots. Plant Breed 130(6): 688-693.

18. Romanchik-Cerpovicz JE, Abbott AE, Dent LA (2011) Sensory Evaluation Ratings and Moisture Contents Show that Soy Is Acceptable 
as a Partial Replacement for All-Purpose Wheat Flour in Peanut Butter Graham Crackers. J Am Diet Assoc 111(12): 1912-1916.

19. Pathomrungsiyounggul P, Lewis MJ, Grandison AS (2010) Effects of calcium-chelating agents and pasteurization on certain properties of calcium-fortified soy milk. Food Chem 118(3): 808-814.

20. AOAC (2003) Official methods of analysis. $\left(17^{\text {th }}\right.$ edn), The Association of Official Analytical Chemists, Arlington, USA.

21. Kirk S, Sawyer R (1991) Pearson's composition and analysis of foods. ( $9^{\text {th }}$ edn), Longman Group Ltd., Harlow, UK.

22. Tulyathan V, Boondee K, Mahawanich T (2004) Characteristics of starch from water chestnut (Trapa bispinosa). J Food Biochem 29(4): 337-348.

23. Benesi IRM, Labuschagne MT, Dixon AGO, Mahungu NM (2004) Stability of native starch quality parameters, starch extraction and root dry matter of cassava genotypes in different environments. J Sci Food Agri 84(11): 1381-1388.

24. AOAC (1984) Official Methods of Analysis. (14 ${ }^{\text {th }}$ edn) The Association of Official Analytical Chemists, Arlington, USA.

25. Garg S, Jana AK (2011) Characterization and evaluation of acylated starch with different acyl groups and degrees of substitution. Carboh Polymer 83(4): 1623-1630.

26. Mweta DE (2009) Physicochemical, functional and structural properties of native Malawian cocoyam and Sweet potato starches. Faculty of Natural and Agricultural Sciences, University of the Free State, Bloemfontein, South Africa.

27. Schmidt KA (2004) Dairy: Ice Cream, in Food Processing: Principles and Applications. Smith JS, Hui YH (Eds.), Blackwell Publishing, Ames, Iowa, USA.

28. Varnam AH, Sutherland JP (1994) Milk and Milk Products,, Food Products Series. Chapman and Hall, London.

29. Olson DW, White CH, Watson CE (2003) Properties of frozen dairy desserts processed by micro-fluidization of their mixes. J Dairy Sci 86(4): 1157-1162.

30. Sevim K, Tekin AR (2011) The effect of salep content on the rheological characteristics of a typical ice-cream mix. J Food Eng 47: 59-62.

31. Bhandari V (2001) Ice Cream manufacture and technology. Tata McGraw Hill Pub Co Ltd, New Delhi, India.

32. Larmond E (1977) Laboratory Methods for Sensory Evaluation of Foods. Canada Department of Agriculture, Pub. No. 1637.

33. Steel RGD, Torrie JH, Dicky DA (1977) Principles and Procedures of Statistics. A Biometrical Approach, $\left(3^{\text {rd }}\right.$ edn), McGraw Hill Book Co. Inc., New York, USA.
34. Jooyandeh H (2011) Soy products as healthy and functional foods. Middle-East J Sci Res 7(1): 71-80.

35. Oladebeye AO, Oshodi AA, Oladebeye AA (2009) Physicochemical properties of starches of Sweet potato (Ipomeabatatas) and red cocoyam (Colocasia esculenta) cormels. Pak J Nutri 8: 313-315.

36. Gomand SV, Lamberts L, Derde LJ, Goesaert H, Vandeputte GE, et al. (2010) Structural properties and gelatinization characteristics of potato and cassava starches and mutants thereof. Food Hydrocol 24(2010): 307-317.

37. Akesowan A (2002) Reduced fat, added konjac gel pork sausage as affected by chopping times. J Inter Soci Southeast Asian Agri Sci 7: 1730.

38. Rezaei R, Khomeiri M, Kashaninejad M, Aalami M (2011) Effects of guar gum and arabic gum on the physicochemical, sensory and flow behavior characteristics of frozen yoghurt. Inter J Dairy Technol 64(4): 563-568.

39. Kanbakan U, Con AH, Ayar A (2004) Determination of microbiological contamination sources during ice cream production in Denizli, Turkey. Food Control 15(6): 463-470.

40. Hematyar N, Samarin AM, Poorazarang H, Elhamirad AH (2012) Effect of Gums on Yogurt Characteristics. World ApplSci J 20(5): 661-665.

41. Tarkash, Yadolah (2005) Ice cream. First print. Ata publisher, Tehran, Pakistan.

42. Guinard JX, Liitle C, Marty C, Palchakz TR (1994) Effect of Sugar and Acid on the Acceptability of Frozen Yogurt to a Student Population. J Dairy Sci 77(5): 1232-1238.

43. Rosalina P, Hartel S, Richard JH (2004) Effects of overrun on structural and physical characteristics of ice cream. Inter Dairy J 14(3): 255-262.

44. Marshall RT, Goff HD, Hartel RW (2003) Ice cream. ( $6^{\text {th }}$ edn), Kluwer Academic/Plenum Publishers, New York, USA.

45. Potter NN, Hotchkiss JH (1995) Food Science. (5 ${ }^{\text {th }}$ Edn), Chapman \& Hall, Public Health Association, Washington, USA.

46. Rothwell J (1995) Defect of Ice Cream arising during distribution and storage, Ice Cream and Frozen Confectionary 45(1): 4-5.

47. Igoe SR (1979) Compositions for stabilizing soft serve and hard frozen yogurt. United States Patent 4178390.

48. RT Marshall, WS Arbuckle, Ice cream, Chapman and Hall, New York, USA.

49. Koxholt MMR, Eisenmann B,Hinrichs J (2001) Effect of the fat globule sizes on the meltdown of ice cream. J Dairy Sci 84(1): 31-37.

50. Goff HD (2001) Controlling ice-cream structure by examining fat: Protein interactions. AustrJ Dairy Technol 55(2): 78-81.

Your next submission with Juniper Publishers
will reach you the below assets
- Quality Editorial service
- Swift Peer Review
- Reprints availability
- E-prints Service
- Manuscript Podcast for convenient understanding
- Global attainment for your research
- Manuscript accessibility in different formats
( Pdf, E-pub, Full Text, Audio)
- Unceasing customer service
Track the below URL for one-step submission
https://juniperpublishers.com/online-submission.php

